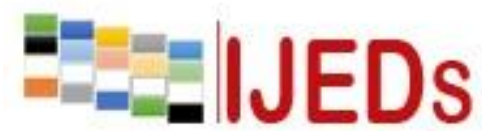

http://ijeds.ppj.unp.ac.id/index.php/IJEDS

\title{
DESCRIPTION TEXT WRITING SKILLS ENHANCEMENT USING GUIDED WRITING PROCEDURE CLASS X2 SMK NEGERI 1 BATIPUH KABUPATEN TANAH DATAR
}

\author{
Delfa Leli \\ Teacher Indonesian SMK 1 Batipuh \\ Email: lelidelfa92@gmail.com
}

*Corresponding Author, Received: November 12, 2019, Revised: December 10, 2019, Accepted: December 21, 2019

\begin{abstract}
This type of research is classroom action research. The research was conducted in the classroom X2 SMK Negeri 1 Tanah Datar Batipuh, The subjects were students of classX2 SMK Negeri 1 Tanah Datar Batipuh the number of students 23 to 10 women and 13 men, Which is listed on the first semestar academic year 2018/2019. The research data was collected through observation, performance, discussion and documentation. The data obtained in the study using qualitative data analysis model.The results of the study illustrate that; 1) Learning to write descriptions have been implemented in accordance with the plan contained in the RPP assessment form. 2) Learning to write descriptions have been conducted using. Method Writing Guided Procedure. In the implementation of student learning has been included in full in the process pemebelajaran. 3) a description of the student writing skills to useMethod Guided Writing Procedure improve. This is evident from the student's skills, where the skills of students in the third cycle is higher than on the skills of writing a description on the second cycle.
\end{abstract}

Keywords : Description Writing Skills, Writing Guided Procedure

\section{INTRODUCTION}

Learning Indonesian basically aims to enhance students' skills to use language as a communication tool, either orally or in writing. This is in accordance with competency standards subjects Indonesian in Education Unit Level Curriculum (MONE, 2006) which states that the competency standards subjects Indonesian-oriented nature of language learning, that learning a language is learning to communicate. 


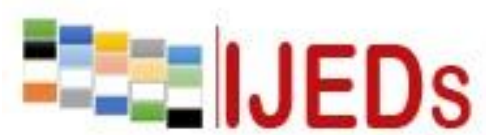

http://ijeds.ppj.unp.ac.id/index.php/IJEDS
International Journal of Educational Dynamics

Vol. 2 No. 1 (pp. 1-8) Desember 2019

p_ISSN 2655-4852

e_ISSN 2655-5093

Text description of the structure and is composed of several different elements forming it with another text, and it is that characterizes that the text is a text description. Lesson write text descriptions contained in the Basic Competency (KD) 1.4 on the syllabus of Indonesian subjects of class $X$ are used inSMK Negeri 1 Tanah Datar Batipuh, KD is "Understanding the written information in various forms of text". Text descriptions tied to competency Dasasr loaded in subjects Indonesian syllabus class X. Therefore, the Indonesian language learning directed to improve the student to communicate orally and in writing. Verbal communication includes listening and speaking activities, while in writing include reading and writing.

Based on the information that the authors obtained dariguru pelaj eyes aran Indonesian who teach in class X SMK Negeri 1 Tanah Datar Batipuh, In writing the text of the description, most of the writing class $\mathrm{X}$ less attractive. According to the teachers, it is also caused by a lack of imagination and creativity of the students to write a text. The lack of essay writing craze is also one factor that led to students' difficulties in writing a text description. Students are also rarely ask questions and express opinions. Discussions between groups rarely do so during the learning interactions between students with each other or with the teacher is still lacking.

Based on these problems, researchers have argued the need for improvement of the learning process in class X SMK Negeri 1 Tanah Datar Batipuh, This is done so that students can play an active role and make it easier for students to write a text description. Students can exchange opinions or brainstorm on a topic that serve as the basis in the text description.

One way is by applying appropriate learning strategies in the teaching of writing, in this case focusing on learning to write the description. Therefore, it is necessary to implement the strategy GWP (Writing Guided Procedures). The strategy is a way to guide students in their ideas, ideas, thoughts, and feelings in writing.

Timayi (2015: 48) explains that the strategy Guided Writing Procedure facilitate the development of writing skills students well by improving their writing test results. The process of writing an expository narrative using GWP strategy, students can be facilitated by the guidance of teachers, guidance teachers on writing so as to provide 


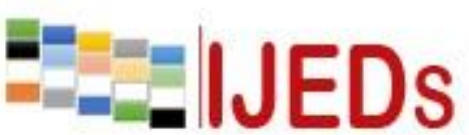

http://ijeds.ppj.unp.ac.id/index.php/IJEDS
International Journal of Educational Dynamics

Vol. 2 No. 1 (pp. 1-8) Desember 2019

p_ISSN 2655-4852

e_ISSN 2655-5093

opportunities for students to be able to cultivate their own ideas but still in accordance with the correct steps in writing and can be monitored by the teacher.

Based on the above, it can be arranged formulation of the problem as follows: Does the application of GWP strategy (Writing Guided Procedures) can improve writing skills writing text description on students X2 class SMK Negeri 1 Tanah Datar Batipuh ?.Researchers are interested in doing research with the title "Writing Skills Improvement Method Using Text Description Writing Guided Procedure X2 grade students of SMK Negeri 1 Tanah Datar Batipuh ",

\section{METHOD}

This type of research is classroom action research (PTK). "PTK (Classroom Action Research) is a systematic review of efforts to improve the implementation of educational practice by a group of teachers to perform actions in learning, based on their reflections on the results of these actions" Ebbut (in Kunandar, 2008: 43). In addition Suharsimi, et al (2007: 102) reveals the classroom action research researcher / teacher can see for themselves the learning practice or with other teachers to do research on students in the learning process.

The research was conducted inX2 SMK Negeri 1 Tanah Datar BatipuhThis research aims to improve text description writing skills learning Indonesian SMK Negeri 1 Batipuh Tanah Datar. The research was conducted in the second half in the vocational school year of 2018/2019. This research requires the implementation time for 4 months, ie from July 172019 until 30 September 2019. consisting of cycle I, II and III.

Observation research data, test results, discussion and documentation of any corrective action related increase writing skills by writing a description text through Method Writing Guided ProcedureX2 grade students of SMK Negeri 1 Batipuh studied. The data contains about matters relating to the planning, execution, and learning outcomes in the form of the following information:

a. Learning is done by Method of Guided Writing Procedure.

b. Implementation of learning related to the behavior of teachers and students that include teaching and learning interaction between teachers and students, students and students, students and teachers in the learning process Indonesian. 


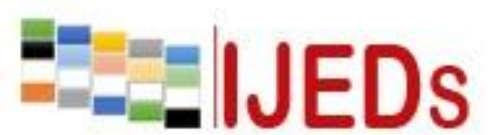

http://ijeds.ppj.unp.ac.id/index.php/IJEDS
International Journal of Educational Dynamics

Vol. 2 No. 1 (pp. 1-8) Desember 2019

p_ISSN 2655-4852

e_ISSN 2655-5093

c. The results of tests carried out after the implementation of student learning measures implemented.

The first source of data in this study were students Class X2 Batipuh SMK Negeri 1 Tanah Datar, In this case the student is a source that can be used to obtain the data. Data obtained in the form of student learning outcomes through learning activitiesWriting Text Description with Method Writing Guided Procedure implemented in the classroom. This research data in the form of observations and interviews from every act of use Method Writing Guided Procedure in learning Writing Text Description graders X2 grade students of SMK Negeri 1 Tanah Datar Batipuh, The data relating to the planning, implementation, and assessment of learning in the form of information.

\section{RESULTS AND DISCUSSION}

In this section presented the research that has been done through the implementation of action research. The implementation stage is the implementation of the action plan implementation of learning by the use Method of Guided Writing Procedure,

\section{First cycle}

Reflection is done collaboratively between practitioners and classroom teacher (observar) on each lesson ends. On this occasion the findings and observations of researchers discussed together. Reflection cycle I include reflection on the planning, implementation, evaluation and the results obtained by the students.

Although the results achieved at sikus I Meeting III had put progress, be it from the planning, implementation and results of the performance in writing the text of the description but researchers feel is not appropriate as expected, with a material that is relatively easy there are still many students who have not memahaminnya well so that there are students who have not completed. Particularly there are several steps in the implementation of Guided Writing Method of Procedure and activities of students during the learning of writing description text that a very small percentage. Researchers wishing more students active and interested, more ask and can answer questions with a good teacher. 


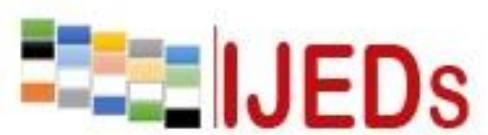

http://ijeds.ppj.unp.ac.id/index.php/IJEDS
International Journal of Educational Dynamics

Vol. 2 No. 1 (pp. 1-8) Desember 2019

p_ISSN 2655-4852

e_ISSN 2655-5093

During the implementation of the measures were analyzed and discussed with the observer in order to obtain the following matters:

a. The lack of guidance teachers in planting in the text description.

b. Lack motivate students at the stage of inquiry when his mastery of text entry so that students are less enthusiastic description in mastering the material. Mastery of this material is very influential in the later stages.

Learning in the first cycle of this first meeting was continued at the meeting 2 . The results of the analysis reflection of the first cycle of the first meeting show the subject has not yet reached the desired learning objectives, namely an increase in the percentage of learning outcomes in accordance with the expected values above $75 \%$ by BSNP (2006: 12), Based on the results of the first cycle carried out as an attempt to improve the writing skills of description text obtained in the first cycle following elaborated on the implementation of the first cycle is not successful therefore be continued in the second cycle.

\section{Cycle II}

From the results of the second cycle of data exposure is known that the learning plan with material to write short stories has been implemented. Implementation Method of Guided Writing Procedure on learning about writing a text description. The observations were obtained from the planning is a researcher has conducted a learning process in accordance with the plan, but its implementation has not been executed in whole or in accordance with a systematic planning that has been made. Although the results achieved in the second cycle has revealed progress, be it from the planning, implementation and activities and the results of the test but researchers have reached the expected.

The reflections on the planning of which is as follows: seen from the results of the second cycle of exposure is known that the learning plan implemented well. In the second cycle research provides learning materials and students perform the steps using the Guided Writing Method of Procedure to obtain data on the results of the implementation of the second cycle of observation and evaluation done Lemar. During 


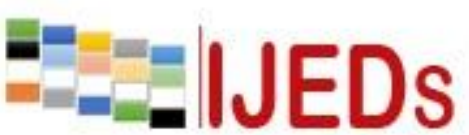

http://ijeds.ppj.unp.ac.id/index.php/IJEDS
International Journal of Educational Dynamics

Vol. 2 No. 1 (pp. 1-8) Desember 2019

p_ISSN 2655-4852

e_ISSN 2655-5093

the implementation of the measures were analyzed and discussed with pengamatam in order to obtain the following matters:

1. Need to be improved to motivate students so that the standard of completeness can be achieved by students.

2. The use of varied media need to be maintained so pleasant learning atmosphere.

3. The results of the acquisition of mastery of students is less than the target set is the completeness completeness $75 \%$ results obtained by the students is $80 \%$.

Learning on the second cycle has seen an increase in learning outcomes in accordance with what is expected.

\section{Cycle III}

From the results of the third cycle of data exposure is known that the learning plan with material to write short stories has been implemented. Implementation Method of Guided Writing Procedure on learning about writing short stories. The observations were obtained from the planning is a researcher has conducted a learning process in accordance with the planning, implementation has been implemented in whole or in accordance with a systematic planning that has been made. results in the third cycle has revealed progress and after in accordance with what is stipulated both the planning, implementation and activities and the results of the test but researchers have reached the expected.

The reflections on the planning of which is as follows: seen from the results of the third cycle of exposure is known that the learning plan implemented well. In the third cycle research provides learning materials and students perform the steps using the Guided Writing Method of Procedure to obtain data on the results of the implementation of the third cycle conducted observation and evaluation sheet. During the implementation of the measures were analyzed and discussed with the observations in order to obtain the following matters:

1. Teachers are already finding ways to motivate students so that the standard of completeness can be achieved by students.

2. The use of varied media need to be maintained so pleasant learning atmosphere. 


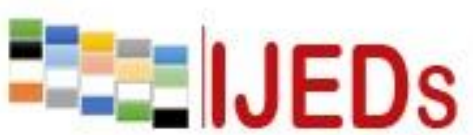

http://ijeds.ppj.unp.ac.id/index.php/IJEDS
International Journal of Educational Dynamics

Vol. 2 No. 1 (pp. 1-8) Desember 2019

p_ISSN 2655-4852

e_ISSN 2655-5093

3. The result of the acquisition of mastery of students in accordance with the targets set, namely by $75 \%$ completeness completeness results obtained by the students are $82 \%$.

Learning in the third cycle has seen an increase in the skill of writing a text description of the study was halted in the third cycle.

\section{CONCLUSION}

Classroom action research conducted in an effort to improve the ability to write text descriptions through guided writing method in class Class 1 Batipuh X2 SMK Tanah Datar, can be implemented properly and increase the ability to write text descriptions once held the action for three cycles. Increased research class action can be known from the results of the learning process and write text descriptions after being given an action using guided writing method. Improved processes can be seen from the students' motivation to get better with the enthusiasm of students in writing a text description with the guided writing method of stimulation images contained in guided writing will help students make the text description woke up with a good student.

Based on the acquisition of a score above, we can conclude that from the second cycle of 75.64, there is an increase of 8.55 , while the final score of the third cycle of 82.42. The use of guided writing method in improving students' writing skills of description text still needs to be developed further so that students can achieve the expected competencies. Therefore, teachers are expected to take advantage of other learning methods as an alternative to learning to write text descriptions for students to be actively involved in learning at the same time it can be easier to understand the learning material.

\section{REFERENCES}

Akhaidah, Sabarti, et al. 2004. Development of Writing Ability Indonesian. Jakarta: Erland.

Alwasilah, A. Chaedar and Suzanna Senny Alwasilah. Anyway 2005. Writing (New Ways of Writing Collaboration Methods). Bandung: PT Qibla Main Book.

Darmadi, kaswan. 1996. Improving Writing Ability. Yogyakarta: Andi.

Department of Education. 2008. Indonesian dictionary. Jakarta: Language Center. 
http://ijeds.ppj.unp.ac.id/index.php/IJEDS

Vol. 2 No. 1 (pp. 1-8) Desember 2019

Timayi, C. (2015). Impact of Guided Writing Strategy on Junior Secondary School Students Writing Competence in Kaduna State, Nigeria. International Journal of Educatinal Research and Information Science, 45-49.

Puji Santoso. (2009). Materials and Development of Indonesian elementary school. Jakarta: UT.

Saleh Abbas. (2006). Indonesian Effective learning in primary schools. Jakarta: Directorate General Education Directorate of Education tow.

Iskandarwassid and Dadang Sunendar. 2008. Language Learning Strategies. Bandung: PT Young Rosdakarya.

Iskandarwassid. \& Suhendar. D. (2013). Language Learning Strategies. Bandung: PT Young Rosdakarya.

Rahman, Hanikara Dahasta (2017) Description Text Writing Skills Improvement Concept Mapping Method Grade 2 Xi-APK SMK PGRI 2 Kediri. Bachelor thesis, University of Brawijaya.

Semi, M. Atar. 1995. Dasat-Basic Writing Skills. Bandung: Mugantara.

Suparno and Mohamad Yunus. 2008. Basic Writing Skills. Jakarta: The Open University.

Slamet. St.Y. (2014). Learning Indonesian Language and Literature in the Classroom Low and High Grade Elementary School. Surakarta: UNS Press.

Enre, Fachruddin Ambo. Keterampulan 1988. Writing Basics. Jakarta: Department of Education.

Keraf, Gorys. 1981. Description and Description. Flores: Nusa Indah.

Nurgiyantoro, Burhan. 2013. Assessment of Competency-Based Language Learning. Yogyakarta: BPFE.

Widarso, Wishnubroto. Tip 2000. Writing in English. Yogyakarta: Canisius.

Sabarti Akhadiah, et al. Indonesian 1992. 1. Jakarta: Ministry of Education and Culture. Indonesian 1993. 2. Jakarta: Ministry of Education and Culture. Indonesian 1993. 3. Jakarta: Ministry of Education and Culture.

Tarin, Henry Guntur. 2008. Writing as A Language Skills. Bandung: Space.

Putranto. (2013). The effectiveness of Guided Writing Strategy Procedure (GWP) in the Short Story Writing Learning SMAN Graders Sewon. P. 25. Thesis S1. Jogjakarta: FBSI UNY.

Kunandar. 2008. Teachers Implementation Unit Level Curriculum (SBC) and Success in Teacher Certification. Jakarta: King Grafindo Persada. 